\title{
ART
}

\section{PAGAN AND CHRISTIAN DUALISM IN THE CULTURE OF ANCIENT RUS}

\author{
Oleg Chuyko, \\ Assistant Professor, Vasyl Stefanyk Precarpathian National University, \\ Assistant Professor of Chair of Design and Art Theory, Ukraine, Ivano-Frankivsk
}

DOI: https://doi.org/10.31435/rsglobal_ws/30042020/7026

\begin{abstract}
ARTICLE INFO
Received: 10 February 2020

Accepted: 04 April 2020

Published: 30 April 2020

\section{KEYWORDS}

syncretism, symbol, mythology, amulet, ritual, ornament, sign.

ABSTRACT

Based on archaeological artifacts, this paper considers another side of Christian and pagan dual faith in the West of Ancient Rus. We analyze material evidence, namely petroglyphs, amulets and ornaments, proving that people still worshiped the pagan deity, Perun, after adoption of Christianity. We place an emphasis on the motif of hatchet which, according to archaic beliefs, is the symbol of weapon, thunder, lightning, heavenly fire and light. We also explore significance of Perun's worship among the princely elite and warriors during the period of forceful unification and defense of the Ruthenian lands.
\end{abstract}

Citation: Oleg Chuyko. (2020) Pagan and Christian Dualism in the Culture of Ancient Rus. World Science. 4(56), Vol.2. doi: 10.31435/rsglobal_ws/30042020/7026

Copyright: (C) 2020 Oleg Chuyko. This is an open-access article distributed under the terms of the Creative Commons Attribution License (CC BY). The use, distribution or reproduction in other forums is permitted, provided the original author(s) or licensor are credited and that the original publication in this journal is cited, in accordance with accepted academic practice. No use, distribution or reproduction is permitted which does not comply with these terms.

Introduction. It is customary to refer to a certain period in spiritual life in Rus after its adoption of Christianity in 988 as Orthodox and pagan syncretism - the term, used by both Ukrainian and European researchers. The situation of dual faith or biculturality, which arose in Rus and got accentuated in the $11^{\text {th }}$ century, could be seen at all levels of medieval public opinion, leaving an impact on the behavior, value-based orientation and practical activities of Ruthenian population. Dual faith was not restricted to beliefs and rites; it also shaped philosophical and ideological ideas of that time, including ethical and aesthetic perception, historical attitude, the idea of society [15].

Archaeologist, historian and ethnographer Mykhailo Klapchuk, while carrying out research on the Pokuttya-Hutsul borderland between Deliatyn and Nadvirna, recorded a number of toponyms derived from names of pagan gods, such as the mountain of Strahora, which rises near the villages of Loieva and Strymba, named in honor of god Stryboh - king-father of winds, heavenly master of storms, tempest, hurricanes $[5,5-10]$.

Studying the proto-Slavic religious center referred to by archaeologists as Loieva Pantheon, M. Klapchuk designated the streams of Bohovets, Velesnytsia, Slobozhnytsia, Khorosna forest, Kostrabky, Divych, Maryn kut, Bohova krynytsia natural bodies and others as sacred micro-toponymy like Strahora. The researcher associates the abundance of these names in a very limited area with names of pagan deities: Stryboh, Diva, Mara, Khors, Kostrub, Dazhboh, Liubizh, Slovboh. Worthy respect in this pantheon was given to god Veles - the patron of peasant households, animals, shepherds, poetry and music, who, in pre-Christian times or the so-called cattle breeding period (late $1^{\text {st }}$ millennium $\mathrm{BC}-$ middle $1^{\text {st }}$ millennium $\mathrm{AD}$ ), was represented as a large bull. It was in honor of Veles that the village of Velesytsia was named, as well as a stream of the same name near Bili Oslavy and two mountain ridges called Velyshche $[10,135]$.

The top of Strahora from Loieva side is called Baba. This toponym, as well as archival records dating back to the $18^{\text {th }}$ century, confirms functioning of a pagan religious structure with a stone idol on 
Strahora. According to Slavic mythology, Stryboh had six sons and six daughters, as well as many winds subject to him; therefore, part of the sanctuary on the eastern slope of Strahora with many hills is called Stryhirchyky.

M. Klapchuk's hypothesis about existence of ancient Loieva sanctuary needed further archaeological confirmation. In 1981, he, together with archaeologist B. Tomenchuk, discovered the settlement of Loieva I, located 300-400 meters from Strahora. During 1981-88, researcher Larysa Krushelnytska carried out excavations of this multi-level monument. The settlement revealed ceramics and other material remains of Lengyel $\left(4^{\text {th }}-3^{\text {rd }}\right.$ millennium BC), Trypillian $\left(4^{\text {th }}-3^{\text {rd }}\right.$ millennium BC$)$, Corded Ware $\left(3^{\text {rd }}-2^{\text {nd }}\right.$ millennium BC), Komariv $\left(15^{\text {th }}-12^{\text {th }}\right.$ centuries BC), Noua $\left(11^{\text {th }}-8^{\text {th }}\right.$ centuries $\mathrm{BC})$ and Holigrady $\left(11^{\text {th }}-8^{\text {th }}\right.$ centuries BC) cultures [11].

Research results. Presumably, inhabitants of this settlement secured the Transcarpathian trade route and were ministers of pagan cult at Loieva sacral center. Probably, in princely times, their ministerial duties were taken over by the boyars, and names of Boyarsky and Boyarchyk natural bodies remained in Dora in their honor. Apparently, the spirit of pagan religion remained in the vicinity of Strahora for a rather long time. Monks of Maniava Monastery were fighting against fading foci of Carpathian paganism in the $17^{\text {th }}$ century, having founded several monastic centers in the Deliatyn region. Legend has it that a hermit monk took up his abode on the hill in the village of Serednii Maidan of Nadvirna Raion, after which this area was called Keliya (monastic cell). The names of Monastyr (monastery) and Cherneche (monastic) natural bodies in the villages of Zarichchia and Krasne also take their origin in the late Middle Ages, when religious communities of monks with their assigned territories separated from Maniava Skete [10, 135].

Ritual practice of ancient pagan religion gives rise to the genesis of amulets, common in the early Christian era. An amulet is a small object, a charm, worn as protection against disasters and diseases. Amulets had the form of a miniature beast, a bird, a sword, an axe and the like.

Having analyzed findings from the 1953-1994 excavations of Zvenyhorod, mentioned in the annals, contemporary researcher Vira Hupalo singled out 34 apotropaic objects related to specific types of spiritual activity. She described charms, such as ceramic pysankas, amulets from wild animals' fangs, wooden sticks with zoomorphic and anthropomorphic endings, as artifacts associated with magic $[6,17-$ 24]. It should be noted that pagan amulets often represent highly artistic jewelry, worn mostly on the neck, as part of necklaces, and sometimes on the belt or on the strap. Some charms display pagan symbols of celestial bodies - the Moon (crescent) and the Sun (circle or diamond) [16, 23].

Excavations of towns of Southwestern Rus often revealed small hatchets with solar symbols on their surface associated with ideas about the celestial bodies and natural phenomena. Researchers' record shows that metal hatches were sacred objects attributed to god Perun [5, 9]. In Kyivan Rus, small replicas of "Perun's Axe" were made of bronze, iron and lead. Russian researcher Vladislav Darkevich collected data on a large series of hatchet pendants and published this information in a special paper [7].

Key conclusions drawn by V. Darkevich include the idea that hatchet amulets symbolized the weapon of the Slavic God of thunder and lightning. The researcher stated that in the $9^{\text {th }}-10^{\text {th }}$ centuries their form was similar to so-called Thor's hammers, often discovered in Scandinavia, Finland and Baltic States. It should be noted that in the Ruthenian period, the shape of miniature axes constantly changed. According to V. Darkevich's classification, in the $11^{\text {th }}-12^{\text {th }}$ centuries, hatchet amulets repeat the shape of a broad-blade, spade-shaped axe [7, 92]. In addition to the above, pagan ritual tradition involved miniature hatchets which were replicas of a broad axe with horn-like protrusions on each side. Precisely such a hatchet was discovered in the village of Zelenche, near Terebovlia, mentioned in the annals [3, 257]. Russian researcher N. Makarov cataloged 62 miniature hatches found within and beyond the borders of Rus [14]. In his opinion, the type of axes with a broad symmetrical blade and horn-like protrusions on each side (Terebovlia discovery) was common in Scandinavia and Baltic states.

In the religious practice of the early Slavs, miniature hatchets came into usage as amulets. The evidence of the above is the discovery of a miniature hatchet in the cultural layer of the $6^{\text {th }}-7^{\text {th }}$ centuries at the excavations of ancient settlement near the village of Zymne (Western Volyn). The amulet is rather small in size: the blade is $4.6 \mathrm{~cm}$ wide and $6.4 \mathrm{~cm}$ long, handle ear diameter is $1.4 \mathrm{~cm}$. [1, 43].

Miniature hatchet amulets have been discovered throughout the territory of Galicia-Volhynia Rus: in a cultural layer of the $10^{\text {th }}-12^{\text {th }}$ centuries in Volyn, in the towns and villages of Drohiczyn, Zhorniv, Zymne, Novyi Maidan, as well as in the neighborhood of Lutsk [12, 44-46] and Plisnesko 
(excavations by M. Fylypchuk). One of the hatchets, probably from princely Halych, is currently housed in the collections of the Ancient Halych National Reserve. Similar artifacts also come from Horodnytsia (Horodenka raion) and from Bukivna (Tlumach raion). A small iron hatchet was found in ancient settlement near the village of Chornivka in Bukovina $[4,125]$.

Hatchet amulets have been decorated with some symbolic ornaments. Vladislav Darkevich singled out the following main elements: zigzag along the hatchet blade, which has represented lightning since ancient times, as well as small concentric circles or circles with a dot in the center, well-known solar symbols. As a hieroglyph in ancient Egypt, this sign meant the day, afterwards was perceived as a solar emblem by the Chinese, and through classical antiquity came to Medieval Europe, where the Slavs and Germans used it to decorate animal figures to emphasize their solar essence [7, 95].

As you can see, hatchets were seen as symbols of thunder, lightning, heavenly fire, the connection being suggested by their ornaments. Axes were used in ceremonial enchantments aimed at protecting the crop from hail and lightning. The axe is also endowed with a special power that brings along fertility of livestock. Moreover, according to academician Boris Rybakov, the axe symbol appears in the wedding ceremony as a protective power not only for crops and livestock, but also for family hearth and childbearing $[17,194]$.

Evidence of the fact that confrontation between supporters of paganism and Christian doctrine was long-living lies in discoveries in Ruthenian Tustan fortress. In 1981, after clearing one of the cliffs on the Urych rock, or Tustan, as this $9^{\text {th }}-10^{\text {th }}$-century monument of ancient Ukrainian art of defense was named by Krakow canon, Jan Dlugosz, in his chronicle, archaeologists recorded petroglyphs of five full size axes, two crosses and one swastika. What's interesting, oblong crosses with extended arm ends, dating from the $12^{\text {th }}-14^{\text {th }}$ centuries, overlapped or crosscut even older petroglyphs depicting axes.

The first builders of Tustan fortress are likely to have arrived at the Urych cliffs in the $9^{\text {th }}$ century. Most of them were pagans and, together with their professional skills, brought along their beliefs, customs and rituals. Axes carved on the rock surface agreed with both their professional etiquette and canons of pagan belief, because in this way Perun, the god of thunder and lightning, was honored. In Indo-European tradition, the common Slavonic worship of Perun was associated with the military function, and it was this god who was considered the patron of armed forces. Perun's weapons included stones ("money stones"), arrows ("thunder arrows") and axe, which became the object of worship [9, 362].

Not only archaeological finds, but also ethnographic sources prove that the inhabitants of the Carpathian foothills believed in the miraculous power of the axe. A well-known ethnographer Volodymyr Kobilnyk described similar practices among peasants of Sambir raion, in particular deification and belief in healing capacity of Neolithic axes with a hole drilled for a wooden handle, in his survey published in Chronicle of Boikivshchyna (Sambir, 1932, No. 3).

In 1975, archaeologist Ya. Borovskyi discovered a Slavic sanctuary on the Perun's hill, under the Trubetskoys mansion in Kyiv. The structure had the form of a rectangle extended from north to south with adjoining six rounded symmetrical protruded petals from the north, east and south, similar to Perun's sanctuary of the $9^{\text {th }}$ century located on the Hnylopiat River near Zhytomyr, as well as Perun's shrine in Novgorod $[8,42]$. It is noteworthy that the above mentioned structure was discovered within the territory where, according to the chronicle, Kyivan Prince Volodymyr Sviatoslavovych, while carrying out nationwide religious reform in 980, laid the foundation of a pagan pantheon in Kyiv, which included six main gods of Kyivan Rus - Perun, Khors, Dazhboh, Stryboh, Simargl and Mokosh [13, 47].

Characteristic of the $10^{\text {th }}$ century ceramic fragments found in the shrine, as well as pieces of an iron battle axe, a symbol of awe-inspiring Perun [2,50-51] discovered in the upper layer, and hatchet amulets, small models of Perun's Axe, which in Kyiv were made from bronze, iron and lead, are also of interest.

Conclusions. Overall, axes found during archaeological excavations, as well as their petroglyphs in the mountainous regions of Ukraine served as a kind of talismans. In particular, they were supposed to help builders in the construction of Tustan fortress and keep its soldiers safe in battle. Based on the detailed study of Velyke Krylo rock, where the petroglyphs of axes and crosses were discovered, archaeologists Mykhailo Rozhko and Mykola Bandrivskyi suggested that in the Ruthenian era the pagan cult of the axe was gradually losing its relevance, together with the worship of its owner, god Perun. Although cross ideograms crosscutting axe petroglyphs in the $12^{\text {th }}-13^{\text {th }}$ centuries, apparently, should indicate "extinction" of the pagan religion [18,82], but abundance of the above motif in places of military force concentration is indicative of durability of Perun worship among the social elite and warriors during the period of forceful unification and defense of the Ruthenian lands. 
Hierarchy of power and authority, the unity between the state and priests of the specified period, led to the social elite of Rus using some elements of pagan culture to consolidate the state power, which proves logical advantage of the concept of "syncretism", compared with the more actively used scientific term "dual faith".

\section{REFERENCES}

1. Aulikh V.V. (1972). Zymnivske horodyshche slovianska pamiatka VI-VII st. n. e. v Zakhidnii Volyni. K.: Naukova dumka, 124. [in Ukrainian]

2. Borovskiy Ya.E. (1982). Mifologogicheskiy mir drevnikh kievlyan. K.: Naukova dumka, 104. [in Russian].

3. Vlasova G.M. (1962). Bronzovye izdeliya XI-XIII vv. iz sela Zelenche. Materialy po arkheologii Severnogo Prichernomorya. Odessa, No.4. 246-259. [in Russian].

4. Voznyi I.P. Chornivska feodalna ukriplena sadyba XII-XIII st. - Chernivtsi: Ruta, 1998. - 153. [in Ukrainian].

5. Voitovych V. (2002). Ukrainska mifolohiia. K.: Lybid, 664. [in Ukrainian].

6. Hupalo V. (2011). Apotropeichni predmety z litopysnoho Zvenyhoroda. Kniazha doba: istoriia i kultura. Lviv, No. IV. 17-34. [in Ukrainian].

7. Darkevich V.P. (1961). Topor kak simvol Peruna v drevnerusskom yazychestve. Sovetskaya arkheologiya. No.4. 91-101. [in Russian].

8. Ivakin H.Yu. (1982). Opovidi pro starodavnii Kyiv. K.: Radianska shkola., 112. [in Ukrainian]

9. Ivanov V.V., Toporov V.N. (2002). Perun. Slavyanskaya mifologiya. M.: Mezhdunarodnye otnosheniya, 362-363. [in Russian].

10. Klapchuk M. (1983). Loievskyi Panteon. Zhovten. No.8. 133-136. [in Ukrainian]

11. Klapchuk M. (1994). Transkarpatskyi shliakh. Starhora. Knyha pro Nadvirnianshchynu. Lviv, 13-18. [in Ukrainian]

12. Kuchynko M., Okhrimenko H., Savytskyi V. (2008). Kultura Volyni ta Volynskoho Polissia kniazhoi doby. Lutsk, 328. [in Ukrainian].

13. Litopys Ruskyi. Za Ipatskym spyskom pereklav L. Makhnovets. K.: Dnipro, 1990. 591. [in Ukrainian].

14. Makarov N.A. (1992). Drevnerusskie amulety-toporiki. Rossiyskaya arkheologiya. No.2. 41-56. [in Russian].

15. Milkov V.V., Pilyugina N.B. (1987). Khristianstvo i yazychestvo: problema dvoeveriya. Vvedenie khristianstva na Rusi. M.: Mysl, 263-273. [in Russian].

16. Sedova M.V. (1981). Yuvelirnye izdeliya drevnego Novgoroda (X-XV vv.). M.: Nauka, 196. [in Russian].

17. Rybakov B.A. (1987). Yazychestvo drevney Rusi. M.: Nauka, 783. [in Russian].

18. Rozhko M., Bandrivskyi M. (1995). Serednovichni petrohlify na Uritskomu kameni. Skeli y pechery $v$ istorii ta kulturi starodavnoho naselennia Ukrainy. Lviv, 80-82. [in Ukrainian]. 